\title{
LETTER
}

\section{Soluble CD40 ligand, a mediator of sepsis or of transfusion-related adverse effects?}

\author{
Pieter R Tuinman* and Nicole P Juffermans \\ See related research by Lorente et al., http://ccforum.com/content/15/2/R97
}

Dr Lorente and colleagues [1] report on the interesting association between serum soluble CD40 ligand (sCD40L) levels and mortality in patients with sepsis. Some variables that can influence outcome in sepsis were accounted for in their analysis. However, the amount of transfused blood products, which may influence levels of sCD40L, was not reported.

SCD40L accumulates to biologically relevant levels during storage of blood products [2,3], in particular of platelet products. Following transfusion, blood products can induce an inflammatory reaction - by activating CD40-positive cells - associated with the occurrence of acute lung injury and other potential serious complications [3]. Levels of sCD40L were also found to be elevated in patients with lung injury following transfusion [2]. Even more, transfusion itself contributes to mortality in the critically ill [4], as well as to adverse outcome of sepsis [5]. Taken together, we suggest that blood transfusion could have potentially influenced both serum sCD40L levels and outcome in the study performed by Lorente and colleagues. The authors state that modulation of $\mathrm{sCD} 40 \mathrm{~L}$ levels could represent a therapeutic target. Would it not be more appropriate to question whether sCD40L from (stored) blood products contributed to elevated serum levels in their trial, before embarking on therapeutic interventions?

\section{Authors' response}

Leonardo Lorente, María del Mar Martín, Nerea Varo and José Antonio Páramo

We read with interest the letter by Tuinman and Juffermans discussing our article recently published in Critical Care [1] showing that circulating levels of sCD40L were associated with mortality in sepsis.

As they stated, the lack of data about blood transfusion is a limitation of our study. In a recently published retrospective cohort study of patients with sepsis by Juffermans and colleagues [5], it was found that transfusion of red blood cells or platelets, and the storage time of red blood cells were associated with the development of nosocomial bacterial infection. On the other hand, another study found that all blood components contained higher levels of sCD40L than fresh plasma (with the highest concentration in platelet concentrates) and that circulating sCD40L levels were higher in patients with lung injury following transfusion [2]. In addition, CD40L

*Correspondence: p.r.tuinman@amc.uva.nl

Department of Intensive Care Medicine and Laboratory of Experimental Intensive Care and Anesthesiology (LEICA), Academic Medical Center, Meibergdreef 9, Amsterdam, $1105 \mathrm{AZ}$, The Netherlands derived from platelets is a potent activator of neutrophils and mediates sepsis-induced neutrophil recruitment and lung edema in mice [6].

Despite this limitation, the results of our study (the largest series reporting data about sCD40L in patients with severe sepsis) suggest that $\mathrm{SCD} 40 \mathrm{~L}$ may be of pathophysiological significance in sepsis due to nonsurvivor patients showing higher sCD40L levels at the moment of diagnosis of severe sepsis than survivor patients. Thus, we think it could be interesting to conduct more research on the role of $\mathrm{sCD} 40 \mathrm{~L}$ in sepsis, and additionally to study the influence of blood transfusion on sCD40L levels and patient prognosis.

\section{Abbreviations}

sCD40L, soluble CD40 ligand.

\section{Competing interests}

The authors declare that they have no competing interests.

Published: 31 May 2011

\section{References}

1. Lorente L, Martín MM, Varo N, Borreguero-León JM, Solé-Violán J, Blanquer J, Labarta L, Díaz C, Jiménez A, Pastor E, Belmonte F, Orbe J, Rodríguez JA, Gómez-Melini E, Ferrer-Agüero JM, Ferreres J, Llimiñana MC, Páramo JA: 
Association between serum soluble CD40 ligand levels and mortality in patients with severe sepsis. Crit Care 2011, 15:R97.

2. Khan SY, Kelher MR, Heal JM, Blumberg N, Boshkov LK, Phipps R, Gettings KF McLaughlin NJ, Silliman CC: Soluble CD40 ligand accumulates in stored blood components, primes neutrophils through CD40, and is a potential cofactor in the development of transfusion-related acute lung injury. Blood 2006, 108:2455-2462.

3. Blumberg N, Spinelli SL, Francis CW, Taubman MB, Phipps RP: The platelet as an immune cell-CD40 ligand and transfusion immunomodulation. Immunol Res 2009 [Epub ahead of print].

4. Marik PE, Corwin HL: Efficacy of red blood cell transfusion in the critically ill: a systematic review of the literature. Crit Care Med 2008, 36:2667-2674.
5. Juffermans NP, Prins DJ, Vlaar AP, Nieuwland R, Binnekade JM: Transfusionrelated risk of secondary bacterial infections in sepsis patients: a retrospective cohort study. Shock 2011, 35:355-359.

6. Rahman M, Zhang S, Chew M, Ersson A, Jeppsson B, Thorlacius H: Plateletderived CD40L (CD154) mediates neutrophil upregulation of Mac-1 and recruitment in septic lung injury. Ann Surg 2009, 250:783-790.

doi:10.1186/cc10237

Cite this article as: Tuinman PR, Juffermans NP: Soluble CD40 ligand, a mediator of sepsis or of transfusion-related adverse effects? Critical Care 2011, 15:4??. 